\title{
Proteins pattern alteration in AZT-treated K562 cells detected by two-dimensional gel electrophoresis and peptide mass
} fingerprinting

\author{
Gabriele D'Andrea*1, Anna R Lizzi ${ }^{1}$, Sara Venditti1, Laura Di Francesco², \\ Alessandra Giorgi $^{2}$, Giuseppina Mignogna ${ }^{2}$, Arduino Oratore ${ }^{1}$ and \\ Argante Bozzi ${ }^{1}$
}

\begin{abstract}
Address: ${ }^{1}$ Department of Biochemical Sciences and Technologies, University of L'Aquila, Via Vetoio, 67100 L'Aquila, Italy and ${ }^{2}$ Department of Biochemical Sciences, University La Sapienza, P.le Aldo Moro 5, 00185 Rome, Italy

Email: Gabriele D'Andrea* - gadan@cc.univaq.it; Anna R Lizzi - lizzi83@hotmail.com; Sara Venditti - sarave77@yahoo.it; Laura Di Francesco - eugenia.schinina@uniroma1.it; Alessandra Giorgi - eugenia.schinina@uniroma1.it; Giuseppina Mignogna - pina.mignogna@uniroma1.it; Arduino Oratore - oratore@univaq.it; Argante Bozzi - bozzi@cc.univaq.it

* Corresponding author
\end{abstract}

Published: 29 March 2006

Proteome Science2006, 4:4 doi:10.1/86/1477-5956-4-4

This article is available from: http://www.proteomesci.com/content/4/I/4

(c) 2006D'Andrea et al; licensee BioMed Central Ltd.

This is an Open Access article distributed under the terms of the Creative Commons Attribution License (http://creativecommons.org/licenses/by/2.0), which permits unrestricted use, distribution, and reproduction in any medium, provided the original work is properly cited.
Received: 15 November 2005

Accepted: 29 March 2006

\begin{abstract}
In this study we report the effect of AZT on the whole protein expression profile both in the control and the AZT-treated K562 cells, evidenced by two-dimensional gel electrophoresis and peptide mass fingerprinting analysis. Two-dimensional gels computer digital image analysis showed two spots that appeared up-regulated in AZT-treated cells and one spot present only in the drug exposed samples. Upon extraction and analysis by peptide mass fingerprinting, the first two spots were identified as PDI-A3 and stathmin, while the third one was proved to be NDPK-A. Conversely, two protein spots were present only in the untreated $\mathrm{K} 562$ cells, and were identified as SODI and HSP-60, respectively.
\end{abstract}

\section{Background}

AZT (3'-azido-3'-deoxythymidine or zidovudine), the first anti-retroviral drug approved for AIDS therapy, is a synthetic nucleoside analogue that inhibits HIV reverse transcriptase activity in vitro [1]. It is often included as one of the best anti-HIV 'drugs of choice' in highly active anti-retroviral therapy (HAART) together with other non-nucleoside analogues and protease inhibitors [2-5]. Besides its inhibitory effect on reverse transcriptase, AZT is known to play a key role in many other cellular processes (e.g. protein and lipid glycosylation [6-8], heme synthesis [9], free radical generation [10-12], apoptosis [13]).
Thus, in the last years, genes responding to AZT have been identified in various cell lines [12-16]. These AZT-modulated genes code mainly for proteins related either to cell growth and/or homeostasis and metabolism. However, recent reports have shown that AZT can also activate a variety of signaling cascades (NF-kB-dependent) involved in many other functions of crucial interest for the cell life [17]. Moreover, AZT is also implicated in the oxidative damage of DNA [18-20] , in the functional impairments and structural destruction of mitochondria $[12,21]$ and in the induction of various transcription factors [14,22-24]. 


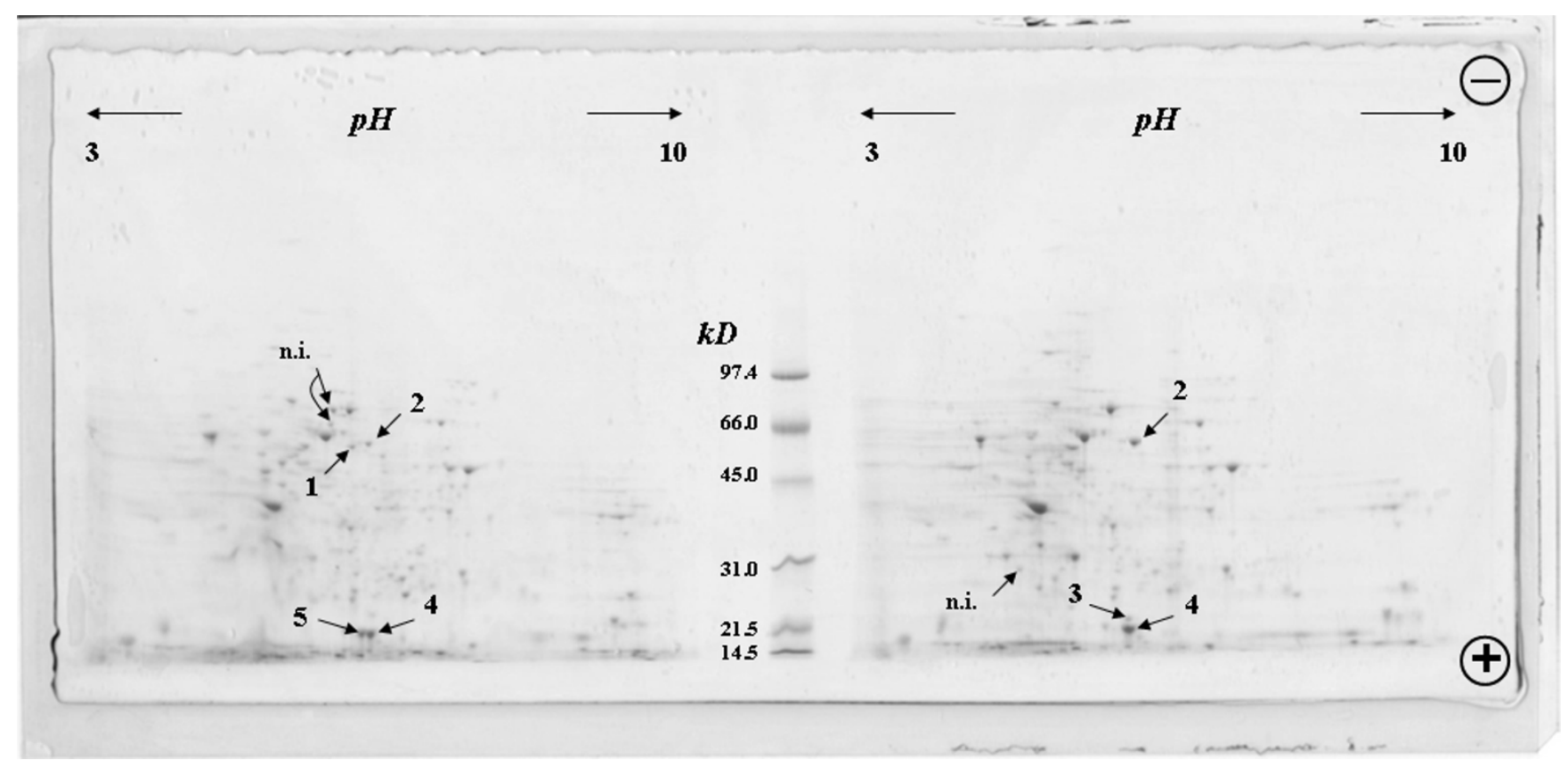

\section{Figure I}

Representative Coomassie Blue G250-stained 2DE gel of K562 cells, developed in the IPG 3-10 linear interval. Left side: control K562 cells; right side: AZT-treated K562 cells. I: HSP-60; 2: PDI-A3; 3: NDPK-A; 4: Stathmin; 5: SODI. n.i.: not identified.

The aim of this study was to extend our knowledge to AZTregulated cellular functions by identifying gene products responsive to AZT. For this purpose we used K562 cells untreated (control), or exposed to $20 \mu \mathrm{M}$ AZT for $3 \mathrm{~h}$. This drug concentration is higher but not far from that found in the blood of AIDS patients under AZT therapy. In addition, $20 \mu \mathrm{M}$ AZT and $3 \mathrm{~h}$ exposure were selected also to enhance the changes of new proteins under AZT influence, and to obtain the major differences without affecting or damaging cells growth. After two-dimensional gel electrophoresis, the protein expression profiles of these two cell samples were previously inspected and then a differential comparison based on peptide mass fingerprinting analysis was performed. Our results showed that, with respect to control cells, AZT-treated cells exhibited PDI-A3 and stathmin up-regulation $(+400 \%$ and $+140 \%$, respectively). On the other hand, SOD1 and HSP-60 were found to be expressed only in control cells, while NADPK-A was evidenced in the AZT-treated samples.

\section{Results and discussion}

To identify the proteins whose expression is responsive to AZT, we performed two-dimensional gel electrophoresis using protein extracts from $\mathrm{K} 562$ cells grown for $3 \mathrm{~h}$ in the absence or in the presence of $20 \mu \mathrm{M}$ AZT. Master maps of control and AZT-treated K562 cells were generated by analysis with the ImageJ software $[25,26]$ after detection of 624 spots by a medium-sensitivity stain such as micellar Coomassie Brilliant Blue G250 [27,28]. Fingerprinting by MALDI-ToF-MS analysis enabled the identification of five different spots.

The major differences found when comparing both sets of samples, the control untreated and the AZT-treated cells, were the up-regulation of two proteins, the apparent induction of a protein and the apparent silencing expression of two proteins by AZT. Following PMF the five proteins were subsequently identified as protein disulfide isomerase A3 (PDI-A3) and stathmin (up-regulated 4 and 1.4 fold, respectively; Fig. 1, right panel); nucleoside diphosphate kinase A (NDPK-A; which was apparently present only in the treated sample; Fig. 1, right panel); cytosolic superoxide dismutase (SOD1) and $60 \mathrm{kDa}$ heat shock protein (HSP-60) (both apparently present only in the control sample; Fig. 1, left panel; Table 1). The identified protein spots indicated in Fig. 1 by figure numbers (1-5) were detected in duplicate in two different sample preparations; the spots indicated in Fig. 1 by n.i. (not identified) appeared only in the representative Coomassie Blue stained 2DE gel (Fig. 1). To our knowledge, this observation is the first one that shows the direct effect of AZT on specific proteins expression.

Our results demonstrated that AZT regulated the expression of PDI-A3, an essential folding catalyst and chaperone of the ER [29-33]. This abundant protein introduces disulfides into proteins (oxidase activity) and catalyzes the rearrangement of incorrect disulfides (isomerase activ- 
ity). Markovic et al. [34] recently confirmed a role for an oxido-reductase activity, presumably that of PDI, in the events that follow the HIV envelop binding to the membrane of cell target receptors. In fact, it has been reported that reduction of gp 120 disulfide bonds by PDI during the viral interaction with the lymphocyte surface is a strict requirement for the fusion [35,36]. However, it has been reported that PDI-A3 may regulate signaling by sequestering inactivated and activated Stat3 [37] and it is usually up-regulated following an ER stress [38,39]. In this respect, intriguingly, although AZT is known to inhibit HIV reverse transcriptase activity, it could partly favor the entry of HIV into the cell through PDI-A3. This hypothesis should be indeed appropriately supported by specific experiments which are beyond the aim of the present study.

The other modulation by AZT of protein expression identified by 2DE was stathmin (oncoprotein 18; phosphoprotein p19) which was 1.4 fold up-regulated in AZTtreated cells. This protein is a regulator of microtubule (MT) dynamics that binds tubulin heterodimers and destabilizes MTs by promoting catastrophes (i.e. transitions from growing to shrinking MTs) [40]. Interestingly, it has been found that microtubule protein contains also an enzyme, namely NDP kinase responsible for the synthesis of nucleoside triphosphates but also involved in several regulatory processes associated with cells proliferation, development, and differentiation [41]. In particular, the so-called NDPK-A, encoded by the nm23-H1 gene, is found only in the cytosol and is associated to tumour progression and metastasis. By contrast, the so-called NDPK-B, encoded by the nm23-H2 gene, is a transcription factor for c-myc and it is found both in the cytosol and in the nuclei [42]. Thus, in our experimental conditions the 1.4-fold up-regulation of stathmin and the concomitant presence of NDPK-A in AZT-treated K562 cells indicated a general effect of the drug on the microtubule system. In this context, it is worth noting that agents able to disrupt microtubules and some routes of intracellular trafficking (e.g. nocodazole, colchicine), reduce the ability of AZT to inhibit the cytotoxicity of ricin because of an alteration in membrane translocation to the cytosol [43].

The last two proteins which appeared to be expressed only in control cells, were identified as HSP-60 and SOD1, respectively. HSP-60 is localized mainly in the mitochondria [44] but it is also described to be associated with the cell membrane $[45,46]$. The major role of HSP-60 is its involvement in the folding of proteins during mitochondrial import; once properly folded the protein become unable to be a target for binding to HSP-60 [47]. Interestingly, it has been reported that HSP-60 interacts with gp41, a transmembrane protein anchoring the surface protein gp120 to the viral envelope of HIV; in addition gp41 mediates the fusion between the viral and the host cell membrane, a step which is essential for viral entry [48]. Since the binding of HSP-60 to gp 41 enhances the infectivity of the virus by helping the virus both to anchor it to the cell surface and to escape the attack of the immune system [48], AZT could reduce the biological activity of gp 41 by silencing the HSP-60 expression, thus preventing the entry of HIV into the cell. This attractive hypothesis, which is linked to gp41 through HSP-60, might counterbalance the effect of AZT on gp120 through PDI-A3, as discussed before. Furthermore, it has also been reported that HSP-60 stimulates the activity of HIV-1 retroviral integrase, an enzyme which catalyzes a critical step in the infectious cycle of this retrovirus, namely the integration of HIV-1 proviral DNA in the nuclear cell genome [49].

Concerning SOD1, the other protein which seemed to be silenced in the presence of AZT, it belongs to a family of ubiquitous enzymes, found in all aerobic cells, which are thought to provide primary defense against deleterious effects of superoxide anions $\left(\mathrm{O}_{2}^{-}\right)$by dismuting them to hydrogen peroxide $\left(\mathrm{H}_{2} \mathrm{O}_{2}\right)$ and molecular oxygen $\left(\mathrm{O}_{2}\right)$ [50]. There are two types of SOD in mammalian tissues: a $\mathrm{Cu}_{2} \mathrm{Zn}_{2} \mathrm{SOD}$ in the cytosol (SOD1 or SOD-c) and a MnSOD in the mitochondria [51]. The SOD1 was identified as spot n. 5 in our 2DE (Fig. 1). Interestingly, it has been previously found that AZT treatment of Tat mice causes almost $80-90 \%$ suppression of Mn-SOD activity [52]. Therefore, a similar effect of AZT on SOD1 can not be excluded in our experimental conditions. Since it has been reported that the extracellular SOD (EC-SOD) activity of blood plasma decreases in HIV-infected patients compared to healthy subjects, and also the SOD activity of mononuclear cells decreases with the HIV-associated disease progression [53], our results are in line with these observations and provide a further tool for a better knowledge of the AZT-induced toxicity in AIDS patients treated with this drug.

\section{Conclusion}

In conclusion, to date, this is the first report showing overexpression of PDI-A3 and stathmin together with NDPKA appearance, in AZT-treated K562 cells, while HSP-60 and SOD1 were detected only in control untreated cells. Of course, up/down regulation of these proteins could be not just exclusive but probably part of a larger group of proteins undetectable with our system. However, further studies are in progress extending our observations to other cell types in order to verify if the above reported alterations are a general feature of the AZT- exposed cells or they represent a peculiar behavior of a specific human chronic myeloid (K562) leukemia cell line. 
Table I: Proteins differentially expressed in AZT-treated K562 cells.

\begin{tabular}{|c|c|c|c|c|c|c|c|}
\hline $\begin{array}{c}\text { Spot } \\
\text { Identification } \\
\text { (Figure I) }\end{array}$ & Protein & Gene name & $\begin{array}{c}\text { SWISS-PROT } \\
\text { accession } \\
\text { number }\end{array}$ & MW (expt/pred) & pl (expt/pred) & $\begin{array}{l}\text { Trend in AZT- } \\
\text { treated cells }\end{array}$ & $\begin{array}{l}\text { Observations and reported } \\
\text { functions a }\end{array}$ \\
\hline 1 & HSP-60 & HSPDI & PI0809 & $61187 / 62000$ & $5.70 / 5.75$ & Absent & $\begin{array}{l}\text { Chaperone that accelerates } \\
\text { the maturation of pro- } \\
\text { caspase by upstream } \\
\text { activator proteases during } \\
\text { apoptosis }\end{array}$ \\
\hline 2 & PDI-A3 & GRP58 & P3010I & $57 \mid 46 / 63000$ & $5.98 / 5.80$ & $\begin{array}{l}\text { Increased } 4.0 \text { - } \\
\text { fold }\end{array}$ & $\begin{array}{l}\text { Chaperone in the } \\
\text { endoplasmic reticulum lumen, } \\
\text { may regulate signalling by } \\
\text { sequestering inactive and } \\
\text { activated Stat3 }\end{array}$ \\
\hline 3 & NDPK-A & NMEI & PI553I & $17309 / 21000$ & $5.83 / 5.90$ & $\begin{array}{l}\text { Present in AZT- } \\
\text { treated cells; } \\
\text { Absent in } \\
\text { control cells }\end{array}$ & $\begin{array}{l}\text { Found in reduced amount in } \\
\text { tumor cells of high metastasic } \\
\text { potential. May have distinct if } \\
\text { not opposite roles in } \\
\text { different tumors }\end{array}$ \\
\hline 4 & $\begin{array}{c}\text { Stathmin } \\
\text { (onco-protein } \\
\text { 18; phospho- } \\
\text { protein pl9) }\end{array}$ & STMNI & PI6949 & $17161 / 19000$ & $5.77 / 5.90$ & $\begin{array}{l}\text { Increased I.4- } \\
\text { fold }\end{array}$ & $\begin{array}{l}\text { Microtubule-destabilizing } \\
\text { proteins up-regulated in } \\
\text { neoplastic cells; down- } \\
\text { regulation in malignant cells } \\
\text { interferes with their } \\
\text { progression through cell } \\
\text { cycle and abrogates their } \\
\text { transformed phenotype }\end{array}$ \\
\hline 5 & $\mathrm{Cu}, \mathrm{Zn}-\mathrm{SOD}$ & SODI & P0044I & $16023 / 19000$ & $5.70 / 5.75$ & Absent & $\begin{array}{l}\text { Cellular protective function } \\
\text { against oxidative stress. } \\
\text { Defects in SODI are the } \\
\text { cause of familial amyotrophic } \\
\text { lateral sclerosis (FALS) also } \\
\text { called amyotrophic lateral } \\
\text { sclerosis I (ALSI or ALS). }\end{array}$ \\
\hline
\end{tabular}

a: from SWISS-PROT entry

\section{Materials and methods Chemicals and materials}

All chemicals, but when specified were from SigmaAldrich (St. Louis, MO, USA). The Multiphor system as well as the linear Immobiline dry strips pH gradient 3-10 (11 cm long) were from Amersham (Milan, Italy).

\section{Cells and growth conditions}

Human chronic myeloid (K562) leukaemia cells were obtained from the American Type Culture Collection (ATCC), maintained in exponential growth in RPMI 1640 bicarbonate medium ( $\mathrm{pH}$ 7.2) supplemented with $10 \%$ $(\mathrm{v} / \mathrm{v})$ heat-inactivated foetal calf serum (FCS), $2 \mathrm{mM}$ glutamine and $0.1 \mathrm{mg} / \mathrm{mL}$ of both penicillin and streptomycin and kept at $37^{\circ} \mathrm{C}$ in a humidified atmosphere of $5 \% \mathrm{CO}_{2}$ in air. Cells, seeded at a density of $3 \times 10^{5}$ cells/ $\mathrm{mL}$, were incubated in the absence or in the presence of 20 $\mu \mathrm{M}$ AZT for $3 \mathrm{~h}$ in routine experiments. Other experimental conditions were also tried (from 2 to $40 \mu \mathrm{M}$ AZT from $5 \mathrm{~min}$ to $48 \mathrm{~h}$ ), but the ones reported here were those that gave both the best reproducibility of the data and the major differences between untreated (control) and AZT- treated cell samples. Therefore, a dose response or a time response curve were not included since not necessary. Cells in the exponential growth phase were harvested for the experiments. However, cell growth did not show any appreciable change at all the experimental conditions we used. Cell counting and viability were determined at various times by trypan blue exclusion method.

\section{Cells treatment for proteomic analysis}

K562 cells, incubated alone or with $20 \mu \mathrm{M}$ AZT for $3 \mathrm{~h}$ at $37^{\circ} \mathrm{C}$, were washed twice with PBS $(20 \mathrm{mM}$ K-phosphate buffer, $\mathrm{pH} 7.2$, containing $150 \mathrm{mM} \mathrm{NaCl}$ ). The pelleted cells $\left(1 \times 10^{6}\right.$ cells $)$ were then treated with $10 \mu \mathrm{L}$ of lysis buffer ( $8 \mathrm{M}$ urea, $2 \%$ CHAPS, $0.3 \%$ DTT, $2 \%$ IPG buffer pH 3-10 (Amersham, Milan, Italy), $5 \mu \mathrm{L}$ bromophenol blue) at $4^{\circ} \mathrm{C}$ for $20 \mathrm{~min}$. Cell extracts were sonicated 4 times for $10 \mathrm{~s}$ each at the maximum power in an ice-bath and then centrifuged for $15 \mathrm{~min}$ at $15,000 \mathrm{~g}\left(4^{\circ} \mathrm{C}\right)$. The clear supernatants containing the proteins solutions were collected and stored at $-80^{\circ} \mathrm{C}$ for no more than a week prior to the subsequent analyses. The protein concentration was determined according to Bradford [54]. 
Table 2: Matching parameters associated to the identified proteins from K562 cells line. (C): control; (T): AZT-treated cells.

\begin{tabular}{ccccc}
\hline Spot Identification (Figure I) & Protein & Sequence Coverage (\%) & Score & Error (ppm) \\
\hline I(C) & HSP-60 & 30 & 95 & 32 \\
$2(\mathrm{C}) 2(\mathrm{~T})$ & PDI-A3 & 1918 & 8886 & 199 \\
$3(\mathrm{~T})$ & NDPK-A & 42 & 60 & 7 \\
$4(\mathrm{C}) 4(\mathrm{~T})$ & $\begin{array}{c}\text { Stathminc (oncoprotein 18; } \\
\text { phosphoprotein p19) } \\
\text { Cu,Zn-SOD }\end{array}$ & 3518 & 6244 & 207 \\
$5(\mathrm{C})$ & 50 & 67 & 19 \\
\hline
\end{tabular}

a: matching with the liver master gel [57].

b: matching with the A549 cells 2D map [58].

c: matching with lymphocyte 2D map [59].

\section{Two-dimensional gel electrophoresis (2DE)}

Approximately $800 \mu \mathrm{g}$ of each sample protein extract were treated with 2-D Clean-Up Kit (Amersham, Milan, Italy) to eliminate high levels of salt and other interfering compounds. The pellets $(200 \mu \mathrm{g})$ were resuspended in $150 \mu \mathrm{l}$ rehydration solution ( $8 \mathrm{M}$ urea, $0.5 \% \mathrm{v} / \mathrm{v}$ Triton $\mathrm{X}-100$, $20 \mathrm{mM}$ DTT, $2 \% \mathrm{v} / \mathrm{v}$ IPG buffer pH 3-10) for the first dimension IEF. Eleven cm long, $\mathrm{pH}$ 3-10 immobilized linear $\mathrm{pH}$ gradient strips were rehydrated with the sample and then focused according to the method of Bjellqvist et al. [55]. Briefly, IPG strips were equilibrated for $10 \mathrm{~min}$ with IPG equilibration buffer (0.5 M Tris-HCl pH 6.8, $6 \mathrm{M}$ urea, 30\% glycerol v/v, 1\% SDS w/v, 0.6\% DTT w/v). After $10 \mathrm{~min}$ the procedure was repeated with another IPG equilibration buffer containing $0.3 \% \mathrm{w} / \mathrm{v}$ IAA instead of DTT and $5 \mu \mathrm{l}$ bromophenol blue solution. For the second dimension, a vertical slab gel of $12.5 \%$ acrylamide was used and SDS-PAGE was performed at $20 \mathrm{~mA}$ per gel for $60 \mathrm{~min}$ at a room temperature. Gels were stained overnight with colloidal Coomassie blue $(0.1 \% \mathrm{w} / \mathrm{v}$ Coomassie Brilliant Blue G250, 34\% v/v methanol, 3\% v/v phosphoric acid, and $17 \% \mathrm{w} / \mathrm{v}$ ammonium sulphate), while destaining was performed with a solution of $5 \% \mathrm{v} /$ $\mathrm{v}$ acetic acid until a clear background was achieved [56]. Five replicas for each conditions (control and AZTtreated) were made. In addition, the same experiments were repeated twice and the spots which were constantly reproduced, as well as those which showed a differential intensity greater than $25 \%$, were analyzed.

\section{Protein pattern analysis}

The 2DE gels were scanned by a standard PC work station and analyzed with the ImageJ software [25,26] (Fig. 1). A match set was created from the protein patterns of the two independent cellular extracts (control K562 cells, AZTtreated K562 cells). Spot amounts of the gels were normalized to remove non-expression-related variations in spot intensity. The results were evaluated in terms of spot pixels. Statistical analysis allowed the study of proteins that were significantly increased (or decreased).

\section{Protein identification by mass spectrometry}

Selected spots were manually excised from gels and a large number of samples were simultaneously digested with trypsin using the In-gel Digest96 Kit ${ }^{\mathrm{TM}}$ (Millipore, Bedford, MA, USA) according to the manufacturer's instructions. A minimal aliquot of the obtained tryptic peptide mixture was mixed with an equal volume of a solution of $\alpha$-cyano4-hydroxy-trans-cinnamic acid matrix, saturated in 50\% v/ $\mathrm{v}$ acetonitrile containing $0.1 \% \mathrm{v} / \mathrm{v}$ TFA, and spotted onto a MALDI target plate. Matrix-assisted laser desorption/ ionization-time of flight-mass spectrometry (MALDI-ToFMS) analyses were performed in a Voyager-DE ${ }^{\mathrm{TM}}$ STR instrument (Applied Biosystems, Framingham, MA, USA) equipped with a $337 \mathrm{~nm}$ nitrogen laser and operating in reflector mode. Mass data were obtained by accumulating several spectra from laser shots with an accelerating voltage of 20,000 V. All mass spectra were externally calibrated using a standard peptide mixture containing desArg-bradykinin (904.4681), angiotensin I (1296.6853), 1-17 (2093.0867) and 18-39 (2465.1989) adrenocorticotropic hormone fragments. Two tryptic autolytic peptides were also used for the internal calibration $(\mathrm{m} / \mathrm{z}$ 842.5100 and 2807.3145) (Table 1). Validation of mass spectrometric identifications was attempted by matching in the Swiss-2DPage database http://www.expasy.ch.

\section{Database searches}

A monoisotopic mass list from each protein spot was obtained from MALDI-ToF data after exclusion of expected contaminant mass values (autolytic tryptic peptides and tryptic human keratin fragments), automatically achieved by the PeakErazor program http://www.pro tein.sdu.dk/gpmaw/Help/PeakErazor/peakerazor.html. These peptide mass fingerprints (PMF) were used to search for human protein candidates in the SWISS-PROT database using the Mascot search engine at the site http:// www.matrixscience.com, with the following parameters: one missed cleavage permission, $50 \mathrm{ppm}$ measurement tolerance and at least five matching peptide masses. Oxidation at methionine (variable modification) and S-car- 
boxyamidomethylation at cysteine residues (fixed modification) were also considered. No post-translational modifications were allowed. Positive identifications were accepted with $P$ values (the probability that the observed match is a random event) higher than 0.05 (Table 2).

\section{Abbreviations}

AZT: 3'-azido-3'-deoxythymidine or zidovudine; 2DE: two-dimensional gel electrophoresis; DTT: 1,4-dithio-DLthreitol; ER: endoplasmic reticulum; HIV: human immunodeficiency virus; HSP-60: $60 \mathrm{kDa}$ heat shock protein; IEF: immunoelectrophoresis; IPG: immobilized pH gradient; MALDI-ToF-MS: matrix-assisted laser desorption/ionization-time of flight-mass spectrometry; NDPK-A: nucleoside diphosphate kinase A; PDI-A3: protein disulfide isomerase A3; PMF: peptide mass fingerprinting; SOD1: cytosolic superoxide dismutase; TFA: trifluoroacetic acid.

\section{Competing interests}

The author(s) declare that they have no competing interests.

\section{Authors' contributions}

GD'A heavily worked out the project, design and drafting of the manuscript; ARL has been involved in seeding, maintenance and treatment of K562 cells; SV carried out two-dimensional gel electrophoresis analyses; LDF participated in protein pattern analysis of digital images; AG performed proteins identification my mass spectrometry; GM participated in database searches; AO participated in the drafting of the manuscript; $\mathrm{AB}$ has been involved as an expert in AZT pharmacology and in critically revising the manuscript.

\section{Acknowledgements}

This work was partially supported by funds from PRIA (Progetti di Rilevante Interesse d'Ateneo) 200I, from PRIN (Progetti di Rilevante Interesse Nazionale, MIUR 2004), and from ex MURST $60 \%$. The authors wish to thank Prof. M.E. Schininà (Centro di Eccellenza di Biologia Molecolare, Università "La Sapienza", Rome, Italy) for her valuable contribution in peptide mass fingerprinting analysis.

\section{References}

I. Mitsuya H, Weinhold KJ, Furman PA, Clair MH St, Lehrman SN, Gallo RC, Bolognesi D, Barry DW, Broder S: 3'-Azido-3'-deoxythymidine (BW A509U): an antiviral agent that inhibits the infectivity and cytopathic effect of human T-lymphotropic virus type III/lymphadenopathy associated virus in vitro. Proc Natl Acad Sci USA 1985, 82:7096-7100.

2. De Clercq E: New developments in anti-HIV chemotherapy. Biochim Biophys Acta 2002, I 587:258-275.

3. Cooper EC: Antiretroviral combination treatment prolongs life in people with HIVIAIDS. AMFAR Re 1996. Jan I-5

4. Del Rio C, Hernandez-Tepichin GH: Optimism rises on combination therapy and protease inhibitor data. AIDS Clin Care 1996, 8:19-20.

5. Mattioli B, Giordani L, Quaranta MG, Viora M: Effect of indinavir used alone or in double or triple combination with AZT and ddC on human immune functions. Life Sci 2004, 74:229I-2300.
6. Hall ET, Yan JP, Melancon P, Kuchta RD: 3'-Azido-3'-deoxythymidine potently inhibits protein glycosylation. A novel mechanism for AZT cytotoxicity. J Biol Chem 1994, 269: I 4355- 14358.

7. Yan JP, Ilsley DD, Frohlick C, Steet R, Hall ET, Kuchta RD, Melancon P: 3'-Azidothymidine (zidovudine) inhibits glycosylation and dramatically alters glycosphingolipid synthesis in whole cells at clinically relevant concentrations. J Biol Chem 1995, 270:22836-2284I.

8. D'Andrea G, Lizzi AR, Brisdelli F, D'Alessandro AM, Bozzi A, Oratore $A$ : Protein glycans alteration and a different distribution of some enzymatic activities involved in the glycan processing are found in AZT-treated $\mathbf{K 5 6 2}$ cells. Mol Cell Biochem 2003, 252:45-5I.

9. Lutton J.D, Mathew A, Levere RD, Abraham NG: Role of heme metabolism in AZT-induced bone marrow toxicity. Am J Hematol 1990, 35: I-5.

10. Szabados E, Fisher GM, Toth K, Csete B, Nemeti B, Trombitas K, Habon T, Endei D, Sumegi $B$ : Role of reactive oxygen species and poly-ADP-ribose polymerase in the development of AZTinduced cardiomyopathy in rat. Free Radic Biol Med 1999, 26:309-317.

II. Valenti D, Atlante A, Barile M, Passarella S: Inhibition of phosphate transport in rat heart mitochondria by 3'-azido-3'-deoxythymidine due to stimulation of superoxide anion mitochondrial production. Biochem Pharmacol 2002, 64:20I-206.

12. Yamaguchi T, Katoh I, Kurata SI: Azidothymidine causes functional and structural destruction of mitochondria, glutathione deficiency and HIV-I promoter sensitization. Eur J Biochem 2002, 269:2782-2788.

13. Collier AC, Helliwell RJ, Keelan JA, Paxton JW, Mitchell MD, Tingle MD: 3'-azido-3'-deoxythymidine (AZT) induces apoptosis and alters metabolic enzyme activity in human placenta. Toxicol Appl Pharmacol 2003, 192:164-173.

14. Bridges EG, Trentesaux C, Lahlil R, Spiga MG, Jeannesson P, Sommadossi JP: 3'-Azido-3'-deoxythymidine inhibits erythroid-specific transcription factors in human erythroid $\mathbf{5 5 6 2}$ leukemia cells. Eur J Haematol 1996, 56:62-67.

15. Komarov AM, Hall JM, Weglicki WB: Azidothymidine promotes free radical generation by activated macrophages and hydrogen peroxide-iron-mediated oxidation in a cell-free system. Biochim Biophys Acta 2004, 1688:257-264.

16. Olivero OA, Tejera AM, Fernandez J], Taylor BJ, Das S, Divi RL, Poirier MC: Zidovudine induces S-phase arrest and cell cycle gene expression changes in human cells. Mutagenesis 2005, 20:139-146.

17. Kurokawa M, Ghosh SK, Ramos JC, Mian AM, Toomey NL, Cabral L, Whitby D, Barber GN, Dittmer DP, Harrington WJ Jr: Azidothymidine inhibits NF-kB and induces Epstein-Barr virus gene expression in Burkitt lymphoma. Blood 2005, 106:235-240.

18. Marty R, Ouameur AA, Neault JF, Nafisi S, Tajmir-Riahi HA: AZTDNA interaction. DNA Cell Biol 2004, 23: I35- 140.

19. Iwamoto T, Hiraku Y, Oikawa S, Mizutani H, Kojima M, Kawanishi S: Oxidative DNA damage induced by photodegradation products of 3'-azido-3'-deoxythymidine. Arch Biochem Biophys 2003, 416:155-163.

20. Slamenova D, Horvathova E, Bartkova M: Nature of DNA lesions induced in human hepatoma cells, human colonic cells and human embryonic lung fibroblasts by the antiretroviral drug 3'-azido-3'-deoxythymidine. Mutat Res 2006, 593:97- 107.

21. De la Asuncion JG, Del Olmo ML, Gomez-Cambronero LG, Sastre J, Pallardo FV, Vina J: AZT induces oxidative damage to cardiac mitochondria: protective effect of vitamins C and E. Life Sci 2004, 76:47-56.

22. Ji HJ, Rha SY, Jeung HC, Yangm SH, An SW, Chung HC: Cyclic induction of senescence with intermittent AZT treatment accelerates both apoptosis and telomere loss. Breast Cancer Res Treat 2005, 93:227-236.

23. Pan G, Wu X, McKenna MA, Feng X, Nagy TR, McDonald JM: AZT enhances osteoclastogenesis and bone loss. AIDS Res Hum Retroviruses 2004, 20:608-620.

24. Freyssenet D, Di Carlo M, Escobar P, Grey J, Schneider J, Hood DA: Zidovudine (AZT) induced alterations in mitochondrial biogenesis in rat striated muscles. Can J Physiol Pharmacol 1999, 77:29-35.

25. Rasband WS: Image]. 1997 [http://rsb.info.nih.gov/ii/]. U.S. National Institutes of Health, Bethesda, Maryland, USA 
26. Abramoff MD, Magelhaes PJ, Ram SJ: Image Processing with Image J. Biophotonics International 2004, I I:36-42.

27. Neuhoff $\mathrm{V}$, Stamm R, Eibl $\mathrm{H}$ : Clear background and highly sensitive protein staining with Coomassie Blue dyes in polyacrylamide gels: A systematic analysis. Electrophoresis 1985, 6:427-448.

28. Neuhoff V, Stamm R, Pardowitz I, Arold N, Ehrhardt W, Taube D: Essential problems in quantification of proteins following colloidal staining with coomassie brilliant blue dyes in polyacrylamide gels, and their solution. Electrophoresis 1990, II:I0I-II7.

29. LaMantia M, Lennarz WJ: The essential function of yeast protein isomerase does not reside in its isomerase activity. Cell 1993, 74:899-908.

30. Laboissiere MC, Sturley SL, Raines RT: The essential function of protein-disulfide isomerase is to unscramble non-native disulfide bonds. J Biol Chem 1995, 270:28006-28009.

31. Gilbert HF: Protein disulfide isomerase. Methods 1998, 290:26-50.

32. Freedman RB, Dunn AD, Ruddock LW: Protein folding: a missing redox link in the endoplasmic reticulum. Curr 1998, 8:R468-R470.

33. Wilkinson B, Gilbert HF: Protein disulfide isomerase. Biochim 2004, 1699:35-44.

34. Markovic I, Stantchev TS, Fields KH, Tiffany LJ, Tomic M, Weiss CD, Broder CC, Strebel K, Clouse KA: Thiol/disulfide exchange is a prerequisite for CXCR4-tropic HIV-I envelope-mediated Tcell fusion during viral entry. Blood 2004, 103:1586-1594.

35. Barbouche R, Miquelis R, Jones IM, Fenouillet E: Protein-disulfide isomerase-mediated reduction of two disulfide bonds of HIV envelope glycoprotein I 20 occurs post-CXCR4 binding and is required for fusion. $J$ Biol Chem 2003, 278:3|3|-3|36.

36. Gallina A, Hanley TM, Mandel R, Trahey M, Broder CC, Viglianti GA, Ryser H]: Inhibitors of protein-disulfide isomerase prevent cleavage of disulfide bonds in receptor-bound glycoprotein 120 and prevent HIV-I entry. J Biol Chem 2002, 277:50579-50588.

37. Guo GG, Patel K, Kumar V, Shah M, Fried VA, Etlinger JD, Sehgal PB: Association of the chaperone glucose-regulated protein $\mathbf{5 8}$ (GRP58/ER-60/ERp57) with Stat3 in cytosol and plasma membrane complexes. J Interferon Cytokine Res 2002, 22:555-563.

38. Hetz C, Russelakis-Carneiro M, Walchli S, Carboni S, Vial-Knecht E, Maundrell K, Castilla J, Soto C: The disulfide isomerase Grp58 is a protective factor against prion neurotoxicity. I Neurosci 2005, 25:2793-2802.

39. Mukhopadhyay S, Shah M, Patel K, Sehgal PB: Monocrotaline pyrrole-induced megalocytosis of lung and breast epithelial cells: Disruption of plasma membrane and Golgi dynamics and an enhanced unfolded protein response. Toxicol Appl Pharmacol 2005 in press. Jul 4

40. Larsson N, Segerman B, Howell B, Fridell K, Cassimeris L, Gullberg M: Op I 8/stathmin mediates multiple region-specific tubulin and microtubule-regulating activities. I Cell Biol 1999, 146: $1289-1302$.

4I. Munier A., Serres C, Kann ML, Boissan M, Lesaffre C, Capeau J, Fouquet JP, Lacombe ML: Nm23/NDP kinases in human male germ cells: role in spermiogenesis and sperm motility. Exp Cell Res 2003, 289:295-306.

42. Pinon VP, Millot G, Munier A, Vassy J, Linares-Cruz G, Capeau J, Calvo F, Lacombe ML: Cytoskeletal association of the $\mathbf{A}$ and $B$ nucleoside diphosphate kinases of interphasic but not mitotic human carcinoma cell lines: specific nuclear localization of the B subunit. Exp Cell Res 1999, 246:355-367.

43. Wellner RB, Pless DD, Thompson WL: Characterization of 3'azido-3'-deoxythymidine inhibition of ricin and Pseudomonas exotoxin A toxicity in $\mathrm{CHO}$ and Vero cells. J Cell Physiol 1994, 1 59:495-505.

44. Morimoto RI, Tissieres A, Georgopoulos G: The biology of heatshock proteins and molecular chaperones. New York: Cold Spring Harbor Laboratory Press; 1994.

45. Poccia F, Piselli P, Vendetti S, Bach S, Amendola A, Placido R, Colizzi $V$ : Heat-shock protein expression on the membrane of $T$ cells undergoing apoptosis. Immunology 1996, 88:6-12.

46. Soltys BJ, Gupta RS: Immunoelectron microscopic localization of the 60-kDa heat shock chaperonin protein (Hsp60) in mammalian cells. Exp Cell Res 1996, 222:16-27.
47. Langer T, Pfeifer G, Martin J, Baumeister W, Hartl FU: Chaperoninmediated protein folding: GroES binds to one end of the GroEL cylinder, which accommodates the protein substrate within its central cavity. EMBO 」 1992, I I:4757-4765.

48. Speth C, Prohaszka Z, Mair M, Stockl G, Zhu X, Jobstl B, Fust G, Dierich MP: A 60 kD heat-shock protein-like molecule interacts with the HIV transmembrane glycoprotein gp4I. Mol Immunol 1999, 36:619-628.

49. Parissi V, Calmels C, De Soultrait VR, Caumont A, Fournier M, Chaignepain S, Litvak S: Functional interactions of human immunodeficiency virus type $I$ integrase with human and yeast HSP60. I Virol 200 I, 75: I I344- I I 353.

50. Bannister JV, Bannister WH, Rotilo G: Aspects of the structure, function and application of superoxide dismutase. CRC Critical Rev Biochem 1987, 22: I 10-180.

5I. Weisiger RA, Fridovich I: Superoxide dismutase. Organelle specificity. J Biol Chem 1973, 248:3582-3592.

52. Prakash O, Teng S, Ali M, Zhu X, Coleman R, Dabdoub RA, Chambers $\mathrm{R}, \mathrm{Aw}$ TY, Flores SC, Joshi BH: The human immunodeficiency virus type I Tat protein potentiates zidovudineinduced cellular toxicity in transgenic mice. Arch Biochem Biophys 1997, 343:173-180.

53. Treitinger A, Spada C, Verdi JC, Miranda AF, Oliveira OV, Silveira MV Moriel P, Abdalla DS: Decreased antioxidant defence in individuals infected by the human immunodeficiency virus. Eur J Clin Invest 2000, 30:454-459.

54. Bradford MM: A rapid and sensitive method for the quantitation of microgram quantities of protein utilizing the principle of protein-dye binding. Anal Biochem 1976, 72:248-254.

55. Bjellqvist B, Sanchez JC, Pasquali C, Ravier F, Paquet N, Frutiger S, Hughes G], Hochstrasser D: Micropreparative two-dimensional electrophoresis allowing the separation of samples containing milligram amounts of proteins. Electrophoresis 1993, 14:1375-1378.

56. Cecconi D, Astner H, Donadelli M, Calmieri M, Missiaglia E, Hamdan M, Scarpa A, Righetti PG: Proteomic analysis of pancreatic ductal carcinoma cells treated with 5-aza-2'-deoxycytidine. Electrophoresis 2003, 24:429I-4303.

57. Sanchez JC, Appel R., Golaz OG, Pasquali C, Ravier F, Bairoch A, Hochstrasser DF: Inside SWISS-2DPAGE database. Electrophoresis 1995, 16:II3I-II5I.

58. Lehner I, Niehof M, Borlak J: An optimized method for the isolation and identification of membrane proteins. Electrophoresis 2003, 24: $1795-1808$.

59. Vuadens F, Crettaz D, Telenti A, Quadroni M, Duchosal MA, Schneider P, Tissot JD: New insights into HIV lymphocyte infection. In Biomedical Application of Proteomics Edited by: Sanchez JC, Corthals GL, Hochstrasser DF. Weinheim: Wiley-VCH; 2004:245-262.

Publish with Bio Med Central and every scientist can read your work free of charge

"BioMed Central will be the most significant development for disseminating the results of biomedical research in our lifetime. "

Sir Paul Nurse, Cancer Research UK

Your research papers will be:

- available free of charge to the entire biomedical community

- peer reviewed and published immediately upon acceptance

- cited in PubMed and archived on PubMed Central

- yours - you keep the copyright
BioMedcentral 